\title{
Study on Production Potential of Rice through Front Line Demonstration in Deoria District of Uttar Pradesh, India
}

\author{
Kamlesh Meena ${ }^{1}$, Anuradha Ranjan Kumari ${ }^{1}$, R.P. Sharma ${ }^{2 *}$ and R. Srivastava ${ }^{1}$ \\ ${ }^{1}$ Krishi Vigyan Kendra (ICAR-IIVR), Malhana, Deoria, U. P., India \\ ${ }^{2}$ Division of Soil Resource Studies, ICAR-National Bureau of Soil Survey and Land Use \\ Planning, Nagpur-440033, India \\ *Corresponding author
}

\section{A B S T R A C T}

\begin{tabular}{|l|}
\hline Key w or d s \\
Front line \\
demonstration, \\
Rice, Impact \\
assessment
\end{tabular}

The development of the agriculture is primarily the application of the science and technology by making the best use of available resources; one of the major constraints of traditionally rice growing varieties is low productivity due to non-adoption of recommended package of practices and improves varieties. Krishi Vigyan Kendra, Deoria under ICAR- Indian Institute of Vegetable Research had conducted Front Line Demonstration (FLD) in adopted farmer fields. Cultivation practices comprised under FLD viz. improved varieties, seed treatment, spacing, balance use of fertilizers, intercultural operations and plant protection measures showed increase in yield of rice from $1.05 \%$ to $51.90 \%$ over local check. Technology gap was lowest $130 \mathrm{~kg} / \mathrm{ha}$ and highest $1090 \mathrm{~kg} / \mathrm{ha}$ was observed. The extension gap in Pusa Sugandha 2511 was higher $(1683 \mathrm{~kg} / \mathrm{ha})$ as compared to technology gap. Technology index was highest $24.22 \%$ in Pusa 519 followed by Pusa $44(24.0 \%)$ and Pusa Sungandha $2511(14.36 \%)$. The lower the value of the technology index indicates the more feasibility of the technology.

\section{Introduction}

In India, rice is the most important and extensively grown food crop for more than two third of the Indian population. During the period $1950-51$ to $2001-2002$, the area has increased by one and half times (31.0 million hectare to 44.6 million hectares), productivity by three times $(668 \mathrm{~kg} / \mathrm{ha}$ to $2086 \mathrm{~kg} / \mathrm{ha})$ and production by four and half time (20.58 million ton to 90 million ton) (Mishra, 2005). But the projected demand for rice is 125 million tons by 2020 at the current rate of population growth.
The agricultural technology is not generally accepted by the farmers completely in all respects. As such there is always appears to be a gap between the recommended technology by the scientist and its modified form at the farmers level.

The technological gap is thus the major problem in the efforts of increasing agricultural production in the country. A need of the day is to reduce the technological gap between the agricultural technology recommended by the scientist and its acceptance by the farmer on their field. 
Keeping this in view the significance of transfer of technology the present investigation was attempt to study the yield gaps between Front Line Demonstration trial and farmers yield, extent of technology adoption and benefit cost ratio.

\section{Materials and Methods}

The study was conducted in Deoria districts of UP during the year 2010-2014. The data on output of different varieties of rice crop and inputs used per hectare have been collected from the Front Line Demonstration trials conducted by Krishi Vigyan Kendra, Deoria. In addition of this, data on traditional practices followed by farmers have also been collected. In the present study, technology index was operationally defined as the technical feasibility obtained by implementation of Front Line Demonstration in rice. To estimate the technology and extension gap and technology index the methodology proposed by Sharma (2004) has been used.

Technology gap $=$ Pi-Di

Extension gap $=\mathrm{Di}-\mathrm{Fi}$

Technology index $=\frac{\text { Pi-Di }}{P_{i}} X 100$

Where

$\mathrm{Pi}=$ Potential yield of the crops.

$\mathrm{Di}=$ Demonstration yield of the crops.

$\mathrm{Fi}=$ Farmers yield

\section{Results and Discussion}

Technology gap, extension gap and technology index

Yield of the Front Line Demonstrations and potential yield of the improved rice varieties were compared to estimate the yield gap which was further categorized into technology gap and extension gap as given in table 1.
In case of rice variety Pusa Sugandha (1121), it is seen that technology gap was lowest (130 $\mathrm{kg} / \mathrm{ha}$ ) in kharif season. Where as in Pusa 519 variety it was highest $(1090 \mathrm{~kg} / \mathrm{ha})$ followed by variety Pusa $44(1080 \mathrm{~kg} / \mathrm{ha})$ in year 2012 . Though the front line demonstrations were laid down in the supervision of KVK scientist in the farmer's field but a significant gap was noted between the potential yield and demonstration yield. This may be due to the variation in soil fertility and weather conditions. Hence location specific recommendations are necessary to bridge the gap. Return on per rupee investment of capital can easily be seen in figure 1 . These findings are similar to the findings of Mandavkar and et al., (2012) and Sharma and Sharma (2004).

Extension gap analysis was done for all rice varieties under demonstrations. It was observed that extension gap of Pusa Sugandha 2511 variety was $1683 \mathrm{~kg} / \mathrm{ha}$ in year 2010 and $959 \mathrm{~kg} / \mathrm{ha}$ in 2011. In case of Pusa Sugandha 1121 variety $840 \mathrm{~kg} / \mathrm{ha}$ extension gap was observed in year 2010. Extension gap in Pusa variety was less than technology gap which is quiet encouraging and need to bring at minimum level. The extension gap in pusa sugandha 2511 and pusa sugandha 1121 was higher as compared to technology gap. This emphasized the need to educate the farmers in adoption of improved technology to narrow down the extension gaps.

\section{Technology index}

The transfer of technology through front line demonstrations was studied through technology Index. It was observed (Table 1) that in kharif season the technology index was highest $24.22 \%$ for pusa 519 variety followed by pusa $44(24.00 \%)$ and pusa sugandha 2511 $(14.36 \%)$ variety of rice. The technology index was low in improved variety Pusa 44 and Pusa sugandha 2511 i.e. $14.66 \%$ and $10.49 \%$, respectively. 
Table.1 Technology gap, extension gap and technology index for different varieties of rice

\begin{tabular}{|c|c|c|c|c|c|c|c|c|c|}
\hline \multirow[t]{2}{*}{ Variety } & \multirow[t]{2}{*}{ Year } & \multirow{2}{*}{$\begin{array}{l}\text { No. of } \\
\text { demo }\end{array}$} & \multicolumn{2}{|c|}{ Yield (kg/ha) } & \multirow{2}{*}{$\begin{array}{l}\text { Farme } \\
\text { rs } \\
\text { field }\end{array}$} & \multirow{2}{*}{$\begin{array}{l}\% \text { increase } \\
\text { in yield over } \\
\text { farmers field }\end{array}$} & \multirow{2}{*}{$\begin{array}{l}\text { Technol } \\
\text { ogy gap } \\
\text { (kg/ha) }\end{array}$} & \multirow{2}{*}{$\begin{array}{l}\text { Extensi } \\
\text { on gap } \\
\text { (kg/ha) }\end{array}$} & \multirow{2}{*}{$\begin{array}{l}\text { Technolo } \\
\text { gy index } \\
(\%)\end{array}$} \\
\hline & & & Potential & demo & & & & & \\
\hline \multicolumn{10}{|l|}{ Paddy (kharif season) } \\
\hline Pusa sugandha 2511 & 2010 & 3 & 5500 & 4923 & 3240 & 51.90 & 577 & 1683 & 10.49 \\
\hline Pusa sugandha 1121 & 2010 & 3 & 4500 & 4370 & 3530 & 6.23 & 130 & 840 & 2.88 \\
\hline Pusa sugandha 2511 & 2011 & 4 & 5500 & 5199 & 4240 & 22.61 & 301 & 959 & 5.47 \\
\hline Pusa sugandha 1121 & 2012 & 5 & 4500 & 4280 & 4190 & 2.14 & 220 & 90 & 4.88 \\
\hline Pusa 519 & 2012 & 2 & 4500 & 3410 & 3220 & 5.9 & 1090 & 190 & 24.22 \\
\hline Pusa 44 & 2012 & 2 & 4500 & 3420 & 3300 & 3.5 & 1080 & 120 & 24.00 \\
\hline Pusa sugandha 2011 & 2013 & 5 & 5500 & 4710 & 4280 & 33.5 & 790 & 430 & 14.36 \\
\hline Pusa 44 & 2013 & 5 & 4500 & 3840 & 3800 & 1.05 & 660 & 40 & 14.66 \\
\hline
\end{tabular}

Table.2 Economics of demonstration of different rice varieties (Rs/ha)

\begin{tabular}{|l|l|l|l|l|}
\hline Rice variety & Gross cost & Gross returns & Net returns & Benefit: cost ratio \\
\hline Pusa Sugandha 2511 & 25180 & 45783 & 20603 & $1.8: 1$ \\
\hline Pusa Sugandha 1121 & 25843 & 40641 & 14798 & $1.6: 1$ \\
\hline Pusa Sugandha 2511 & 26750 & 57189 & 30439 & $2.1: 1$ \\
\hline Pusa Sugandha 1121 & 29500 & 51360 & 21860 & $1.7: 1$ \\
\hline Pusa 519 & 28220 & 35510 & 7209 & $1.3: 1$ \\
\hline Pusa Sugandha 2511 & 27850 & 37620 & 9770 & $1.4: 1$ \\
\hline Pusa Sugandha 2511 & 27340 & 80024 & 52680 & $2.9: 1$ \\
\hline Pusa 44 & 26810 & 46080 & 19270 & $1.7: 1$ \\
\hline
\end{tabular}

Fig.1 Net returns of rice varieties in FLDs at farmers' fields of Deoria

\section{Net returns of rice varieties in FLDs}

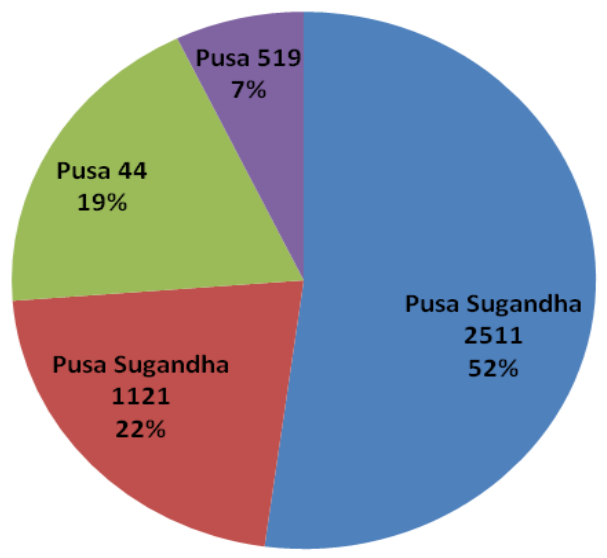


Technology index showed the feasibility of the evolved technology on the farmer's field. The lower the value of the technology index more is the feasibility of the technology. The findings are in line with the findings of Singh et al., (2007).

Per hectare cost of cultivation of improved variety pusa sugnadha 2511 and pusa sugnadha 1121 was almost equal (Table 2). Among the four rice varieties gross return from pusa sugnadha 2511 was highest (Rs 80024 ) as compared to variety pusa sugandha 1121, pusa 519 and pusa 44 . The benefit cost ratio of variety pusa sugnadha 2511 was 2.9 in year 2013. Under this study the yield of the rice variety was directly influenced by the benefit cast ratio. The adoption of recommended practices in front line demonstration trials on rice has increased the yield over the respective check varieties. These findings are similar to the findings of Suryawanshi and Prakash (1993).

The findings of the study revealed that wide gap existed in potential and demonstration yield in rice varieties due to technology and extension gap in Deoria district of Uttar Pradesh. By conducting Front Line Demonstrations of proven technologies the yield of rice can be increased to a great extent. This will substantially increase the income as well as the livelihood of the farming community. There is need to adopt multi-pronged strategy that involves enhancing rice production through improved technologies in Deoria district. The study emphasized the needs to educate the farmers in adoption of improved technology to narrow the extension gaps through various technology transfer centers.

\section{References}

Mandavkar, P. M., Sawant, P. A. and mahadik, R. P. 2012. Evaluation of Front Line Demonstration trials on rice in raigad district of Maharashtra. Rajasthan Journal of Extension Education. 20:4-6.

Mishra, B., 2005. More crop per drop. The Hindu, Survey of Indian agriculture: 41

Sharma, R. N. and Sharma, K. C. 2004. Evaluation of Front Line Demonstration trials on Oilseeds in Baran district of Rajasthan. Maharashtra Journal of Extension Education. 7:72-75.

Singh, T., Vyas, M. D., Saxena, Arvind and Jain, Anil 2007. Impact of new technologies on Soyabean at farmers' field, Indian Research Journal of Extension Education 7(1):39-40.

Suryawanshi, S. D. and Prakash, M. 1993. Impact of vialble technology of promoting oil seeds in Maharashtra, Indian Journal of Agricultural Economics. 48:420.

\section{How to cite this article:}

Kamlesh Meena, Anuradha Ranjan Kumari, R.P. Sharma and Srivastava, R. 2018. Study on Production Potential of Rice through Front Line Demonstration in Deoria District of Uttar Pradesh, India. Int.J.Curr.Microbiol.App.Sci. 7(01): 328-331. doi: https://doi.org/10.20546/ijcmas.2018.701.036 